\title{
MICROELEMENT COMPOUNDS IN HEALTHY LONG AND IRREGULAR BONES
}

\author{
Maksym Pogorielov, Evgenii Gusak¹, Sergii Danilchenko', Gennadii Tkach, \\ Oksana Pogorielova, Vladimir Deineka, Vitalii Sikora \\ Sumy State University, Sumy, Ukraine \\ ${ }^{1}$ Institute of Applied Physics, Sumy, Ukraine
}

\begin{abstract}
PURPOSE: One of the most important functions of the osseous tissue is to deposit macro- and microelements. For that reason, the investigation of the skeleton ion profile is highly important to explain the physiological and reparative osteogenesis. The osseous tissue, compared to blood, is a more stable system and ion concentration in bone can display the chronic disorders of its metabolism and its distribution around the body. Ion disbalance can affect bone cells and change the structure and function of the skeleton. The long and irregular bones have different metabolic activities and vascularization, so the ion distribution must be different, but information about ion balance is not clear. This determined the purpose of the research, which deals with microelement compounds of tibia, femoral bone and $2^{\text {nd }}$ lumbar vertebra.

MATERIAL AND METHODS: The paper deals with analysis of osseous tissue samples from 20 5-monthold white rats. We measured the levels of $\mathrm{Fe}, \mathrm{Mg}, \mathrm{Zn}, \mathrm{Cu}, \mathrm{Co}, \mathrm{Mn}, \mathrm{Ni}, \mathrm{Pb}$ and $\mathrm{Cd}$ in tibia, femur and $2^{\text {nd }} \mathrm{lum}$ bar vertebra. The research results were analyzed according to generally accepted methods of variance analysis with the help of MS Excel software program.

RESULTS AND CONCLUSIONS: The elemental analysis of different bone types shows diversities between tubular and irregular bones' microelement composition. The lumbar vertebrae contain a great amount of essential elements which is related to its remodeling activity and availability of enzymes. Mostly the long bones store toxic elements, such as $\mathrm{Ni}$ and $\mathrm{Pb}$. This indicates a lower speed of the remodeling process of compact substance. Thus, elementary bone compounds directly depend on osseous tissue structure.
\end{abstract}

Keywords: long bones, irregular bones, trace elements

\section{INTRODUCTION}

Osteogenesis stimulation is one of the underinvestigated issues nowadays, as well as the topical problem of traumatology. One of the most important functions of the osseous tissue is depositing of macro- and microelements and due to this research

\footnotetext{
Address for correspondence:

Pogerelov Maksym Vladimirovich

31 Sanatornaya str., Sumy, Ukraine, 40018.

Fax/phone: +380669005448

e-mail:pogorelov_max@mail.ru
}

Received: August 13, 2013

Accepted: February 11, 2014 on the skeleton ion profile it is highly important to explain the osteogenesis physiological and reparative processes (1). Some microelements are involved in enzyme catalysis reactions, which are held in the osteogenic cells, so in case of their deficit or imbalance, some processes are interrupted: such as osteoblastic and osteoclastic differentiation, apatite crystallization process, cell-cell collaboration (2). These all cause physiological and reparative remodeling changes of bones.

Apart from $\mathrm{Ca}$ and $\mathrm{P}$, which are the basic composite elements, there are other elements in the osseous tissue. Some cations can displace the hydroxyapatite crystalline grid, while other elements are adsorbed on the nanocrystal surface or on its hydrat- 
ed film. All elements can be divided into synergist and antagonist groups. The former include calcium and phosphorus, which synergism in the formation and remodeling of bone tissue has been well studied. The other example is $\mathrm{Fe}$ and $\mathrm{Cu}$, which are involved in the cytochrome oxidase active site formation. The antagonistic interaction includes the retarded influence of $\mathrm{Ca}$ on zinc and magnesium absorption, ion's contest for enzyme system active sites, such as divalent $\mathrm{Mg}$ and $\mathrm{Mn}$ of metalloenzymic complexes of alkaline phosphatase. The vital, essential elements are also distinguished, such as $\mathrm{Fe}, \mathrm{Cu}, \mathrm{Zn}, \mathrm{Co}, \mathrm{Cr}, \mathrm{Mo}$, $\mathrm{Mn}$. Ni is the conditionally essential element (3). The following microelements, $\mathrm{Cd}$ and $\mathrm{Pb}$, can cause intoxication, since they have a tendency to accumulate in osseous tissue and belong to the toxic elements (4).

Bone repairing processes require many microelements to be active, such as $\mathrm{Cu}, \mathrm{Mn}, \mathrm{Pb}, \mathrm{Co}$, etc. $\mathrm{Mi}$ croelements have an important role in oxidation-reduction processes, where they speed up the catalysis reactions. Besides, these microelements promote and control abiotic polymerization. During the mucopolysaccharide synthesis a great amount of microelements such as $\mathrm{Mn}, \mathrm{Pb}, \mathrm{Cu}$ are concentrated in a fracture site. $\mathrm{Cu}, \mathrm{Mn}, \mathrm{Co}$ and some others are involved in enzyme catalysis reactions and their absence interrupts osteoblastic differentiation (5). A lack or an imbalance of some microelements $(\mathrm{Mn}, \mathrm{Pb}, \mathrm{Cu})$ can cause osseous tissue spontaneous decalcifation rickets, hypothyroidism, osteoporosis and other pathologies (6). The osseous tissue contains a variety of microelements and their number and functions are not properly studied. They are $\mathrm{Cr}, \mathrm{Cd}, \mathrm{Te}, \mathrm{In}, \mathrm{Sm}, \mathrm{Ru}, \mathrm{Sc}$, $\mathrm{Zr}$, Hf, etc.

The osseous tissue, compared to blood, is a more stable system and ion concentration in bone can display the chronic disorders of its metabolism and its distribution around the body. Ion disbalance can affect bone cells and change the structure and function of the skeleton. On the other hand, the accumulation of microelements may be asymptomatic for a long time, and detecting the increased content of trace elements can be used to assess environmental pollution. It should be noted that irregular element distribution in the skeleton depends on the type of bone.
Unfortunately, there are no data in the literature about the distribution of trace elements around the different types of the bones and their interaction. Nevertheless, it is well known that microelements have a wide variety of synergetic and antagonistic interactions. Additionally, 15 vital elements have 105 bilateral and 455 trilateral interactions $(7,8,9)$. Given the wide range of interactions between ions, it is important to consider not only their absolute content in bone, since increase in value in one of the elements can lead to a significant reduction in the other. Thus the imbalance of one micronutrient elements can lead to a violation of a number of metabolic systems.

These factors determine the purpose of our research, which deals with the microelemental composition of tibia, femoral bone and $2^{\text {nd }}$ lumbar vertebra. We aim to perform a correlation analysis between identified elemental levels to understand ion interaction in different bone types.

\section{MATERIALS AND METHODS}

The paper deals with analysis of osseous tissue samples from 205 -month-old white rats (that corresponds to adult age). During the research the femoral bone, tibia and $2^{\text {nd }}$ lumbar vertebra were investigated for microelement composition. The animals were decapitated under ketamine anesthesia to collect organ recovery sampling. This process was carried according to the statements of the "European Convention on Vertebrate Animal Protection, which are used for Experiments and Other Scientific Aims" (Strasbourg, 1986), "General Ethnic Principals about Experiments on Animals", which were accepted by the First National Congress on Bioethics (Kyiv, 2001).

The bone samples were cleared from muscular tissue and bone marrow, degreased with ethanol, washed with distilled water and their weight was measured with an accuracy of $0.001 \mathrm{~g}$. After that the bones were burned in a sound suppression muffle at $450 \mathrm{C}^{0}$ to eliminate the organic matrix. When the ash was taken out, it was dissolved in a mixture of $0.1 \mathrm{M}$ hydrochloric $(2 \mathrm{ml})$ and $0.1 \mathrm{M}$ nitric $(1 \mathrm{ml})$ acid and 7 $\mathrm{ml}$ of distillated water.

The samples were analyzed using an atomic absorption spectrophotometer C 115-01 with flame atomizer ("Selmi", Ukraine) and a double-beam atomic absorption spectrophotometer KAS 120.1 ("Selmi”, Ukraine) with a deuterium corrector of non- 
Maksym Pogorielov, Evgenii Gusak, Sergii Danilchenko et al.

atomic absorption. Hollow cathode lamps were used as the source of radiation. A standard pyrolytic graphite furnace, $28 \mathrm{~mm}$ long, inner diameter $6 \mathrm{~mm}$, was used as atomizer. The acquisition and analysis of the atomic absorption signal were performed using an IBM PC (AAS-SPECTR program) (10). $10 \mu \mathrm{l}$ of samples were dosed immediately onto the inner surface of the furnace. Aqueous calibration solutions of corresponding metals were used for the quantitative analysis. The standard solutions were prepared from pure substances of the corresponding metal salts.

The measurements of $\mathrm{Pb}$ absorption were performed at $283.3 \mathrm{~nm}$ resonance line with a spectral bandpass of $0.4 \mathrm{~nm} ; \mathrm{Fe}-$ at $248.3 \mathrm{~nm}$ resonance line with a spectral bandpass of $0.4 \mathrm{~nm} ; \mathrm{Mg}$ - at $285.2 \mathrm{~nm}$ resonance line with a spectral bandpass of $0.4 \mathrm{~nm}$; $\mathrm{Zn}$ - at $213.9 \mathrm{~nm}$ resonance line with a spectral bandpass of $0.4 \mathrm{~nm} ; \mathrm{Cu}-324.7 \mathrm{~nm}$ resonance line with a spectral bandpass of $0.1 \mathrm{~nm}$; Co $-240.7 \mathrm{~nm}$ resonance line with a spectral bandpass of $0.4 \mathrm{~nm} ; \mathrm{Mn}-$ $271.4 \mathrm{~nm}$ resonance line with a spectral bandpass of $0.1 \mathrm{~nm} ; \mathrm{Ni}-232.0 \mathrm{~nm}$ resonance line with a spectral bandpass of $0.1 \mathrm{~nm}$; $\mathrm{Cd}-228.8 \mathrm{~nm}$ resonance line with a spectral bandpass of $0.4 \mathrm{~nm}(11,12,13)$. Matrix and surface modifiers were not used.

When the identification procedure of the elements in the solution was performed, the sample was inserted and the element concentration in $1 \mathrm{~g}$ of the studied tissue was determined. The measurements and calculations were done using the AAS-SPECTR program in the Atomic-Absorption Analysis Labo- ratory of Anatomic Research Center of Sumy State University.

\section{Statistical analysis}

The results were analyzed statistically using the following method of correlation analysis with the help of MS Excel. The type and features of biological metal interaction was found out by means of a straight-line paired regression equation. Correlation coefficient ( $r$ ) was used to estimate the degree of linear interactions among variables. The educts were analyzed according to common quality regression level, the coefficient of multiple determination $\mathrm{R}^{2}$ was determined too. This coefficient determines the percentage of the obtained regression function and how the latter shows the correlation between data values.

\section{RESULTS AND DISCUSSIONS}

The osseous tissue chemical compound analysis proved the presence of elements such as $\mathrm{Fe}, \mathrm{Mg}$, $\mathrm{Zn}, \mathrm{Mn}, \mathrm{Cu}, \mathrm{Co}, \mathrm{Cd}, \mathrm{Ni}, \mathrm{Pb}$. Element concentrations correspond to literature data $(14,15)$. The contrastive analysis among microelements concentration measures gave an opportunity to identify the next tendency $\mathrm{Zn}>\mathrm{Mg}>\mathrm{Fe}>\mathrm{Ni}>\mathrm{Cu}>\mathrm{Mn}>\mathrm{Co}>\mathrm{Pb}>\mathrm{Cd} \quad$ (Table 1). These trends confirm the essentiality of some microelements for the osseous tissue.

$\mathrm{Zn}$ is one of the most spread elements in the human body (16). It plays an important role in the mechanical properties and osseous tissue formation processes. $\mathrm{Zn}$ inhibits the influence of parathormone and stimulates bone synthesis processes (17). Even in

Table 1. Average Microelement Amount in Rats' Osseous Tissue

\begin{tabular}{lccc} 
Microelement & Femur & Tibia & Lumbal vertebra \\
$\mathrm{Fe} \mu \mathrm{g} / \mathrm{g}$ & $64,60 \pm 3,65$ & $55,00 \pm 5,87$ & $127,47 \pm 12,06$ \\
$\mathrm{Mg} \mu \mathrm{g} / \mathrm{g}$ & $1,94 \pm 0,25$ & $2,52 \pm 0,35$ & $3,07 \pm 0,18$ \\
$\mathrm{Zn} \mu \mathrm{g} / \mathrm{g}$ & $3,32 \pm 0,24$ & $5,31 \pm 0,62$ & $3,71 \pm 0,14$ \\
$\mathrm{Cu} \mu \mathrm{g} / \mathrm{g}$ & $2,36 \pm 0,31$ & $2,53 \pm 0,26$ & $4,23 \pm 0,47$ \\
$\mathrm{Co} \mu \mathrm{g} / \mathrm{g}$ & $1,41 \pm 0,09$ & $1,52 \pm 0,22$ & $2,44 \pm 0,29$ \\
$\mathrm{Mn} \mu \mathrm{g} / \mathrm{g}$ & $1,93 \pm 0,26$ & $2,44 \pm 0,18$ & $2,66 \pm 0,43$ \\
$\mathrm{Ni} \mu \mathrm{g} / \mathrm{g}$ & $2,38 \pm 0,56$ & $4,00 \pm 0,87$ & $4,95 \pm 0,96$ \\
$\mathrm{~Pb} \mu \mathrm{g} / \mathrm{g}$ & $0,86 \pm 0,04$ & $0,66 \pm 0,09$ & $0,51 \pm 0,06$ \\
$\mathrm{Cd} \mu \mathrm{g} / \mathrm{g}$ & $0,024 \pm 0,001$ & $0,025 \pm 0,002$ & 0 \\
\hline
\end{tabular}


case of low concentration of this element, it still slows the bone-resorbing cell activity. It doesn't have toxicity features, unlike microelements such as $\mathrm{Pb}$ and $\mathrm{Cd}$. Besides, it has a positive influence on increasing intracellular calcium content and redirects the calcium level in the cytosol (18). It also serves as an inhibitor for iron-bearing cytochrome oxidase and catalase ferments, which play the key role in increasing the number of bone-forming cells for the biosynthesis of collagen. It acts on the alkaline phosphatase and controls the calcitonin secretion. We established in the analyzed bones a $\mathrm{Zn}$ content of $3.32 \pm 0.24 \mu \mathrm{g} / \mathrm{g}$ in femur and $3.71 \pm 0.41 \mu \mathrm{g} / \mathrm{g}$ in vertebra and up to $5.31 \pm 0.62 \mu \mathrm{g} / \mathrm{g}$ in tibia. In view of its physiological position, the derived difference can point to an existence of more active remodeling processes in the tibia. The $\mathrm{Zn}$ level in tibia is significantly higher compared to femur and vertebrae.

$\mathrm{Mg}$ is the second wide-spread cation of the human body after $\mathrm{Ca}$. The skeletal system and soft tissues have approximately the same amount of $\mathrm{Mg}$. One-third of skeletal Mg is spread on bone surfaces and functions as a repository (19). Abrupt changes of $\mathrm{Mg}$ concentration have a stimulatory effect on parathyroid hormone secretion. Lack of $\mathrm{Mg}$ causes hypocalcemia. It reduces osseous tissue extension and appropriate resorption processes, bone volume and expands brittleness of skeleton. $\mathrm{Mg}$ is a cofactor of many enzymes, such as the alkaline and pyrophosphatase, which have a direct effect on osseous tissue formation (20). There is a competition between $\mathrm{Ca}$ and $\mathrm{Mg}$ due to the very close ionic radiuses. Extremely high concentrations of $\mathrm{Mg}$ have an inhibitory effect on the hydroxylapatite crystallization process (21). Pathogenic biominerals contain it, where $\mathrm{Mg}$ exchanges $\mathrm{Ca}$ on the hydroxylapatite grid. The presence of $\mathrm{Mg}$ in the hydroxylapatite lattice reduces Ca solubility. Besides, increase in $\mathrm{Mg}$ concentration in the synthetic hydroxylapatite grid reduces its phasic disintegration temperature, while $\beta$-tricalcium magnesium phosphate is formed $(\mathrm{CaMg})_{3}\left(\mathrm{PO}_{4}\right)_{2}$ and the phasic formed number of $\beta$-TCMP is proportional to the Mg level of apatite. The highest $\mathrm{Mg}$ concentration in our research was found in the tibia and vertebrae $-2.52 \pm 0.35 \mu \mathrm{g} / \mathrm{g}$ and $3.07 \pm 0.18 \mu \mathrm{g} / \mathrm{g}$, respectively, the lowest level were in the femoral bone $(1.94 \pm 0.25 \mu \mathrm{g} / \mathrm{g})$. So, we observed a significant differ- ence only between the level of $\mathrm{Mg}$ in vertebrae and femur.

$\mathrm{Cu}$ acts as a cofactor of many essential enzyme systems in osteogenic cells and at the same time controls the differentiation level (22). Probably $\mathrm{Cu}$ has a function of energy transport mechanisms between apatite and collagen. The highest content of this element was found in new osteons. Cuprum takes place in collagen and elastin fusion processes and prevents from osseous tissue demineralization (23). The long bones revealed the same cuprum level $-2.36 \pm 0.31$ $\mu \mathrm{g} / \mathrm{g}$ for the femoral bone, and $2.35 \pm 0.26 \mu \mathrm{g} / \mathrm{g}$ for the tibia. At the same time the lumbar vertebra contained $4.23 \pm 0.47 \mu \mathrm{g} / \mathrm{g}$ of cuprum which is significantly higher compared to other bones. These results confirmed the notion that irregular bones have a better accumulation function for cuprum-dependent enzymes and cuprum itself.

Manganese is mostly related to the osseous tissue inorganic structure of bones and is directly involved in the ossification process - it promotes the hydroxylapatite crystals growing process (24). Mn also contributes to the mineralization of collagen fibrilla, normalizes the glycosaminoglycan fusion, which is involved in the osseous and cartilage tissue formation. Manganese content did not have sharp diversities depending on tissue type and it varied from $1.93 \pm 0.26 \mu \mathrm{g} / \mathrm{g}$ to $2.66 \pm 0.43 \mu \mathrm{g} / \mathrm{g}$ in wet bone.

Co stimulates hemopoiesis and thus it has a secondary influence on bone metabolism intensity (25). Cobalt-containing compounds enforce the alkaline phosphatase potency, which plays an important role in the osseous tissue mineralization process (26). The long bones contained the same content of $\mathrm{Co}$ - from $1,44 \pm 0,09 \mu \mathrm{g} / \mathrm{g}$ to $1,52 \pm 0,22 \mu \mathrm{g} / \mathrm{g}$. Despite this, the lumbar vertebra had a significantly higher level of Co $-2,44 \pm 0,29 \mu \mathrm{g} / \mathrm{g}$.

Iron is not a structural element of the osseous tissue, however it plays a key role in the osteogenesis process (27). It affects the hydroxyapaptite stabilization of the osteoid substance due to its storage in enchondral and periosteous bone formation areas. Fe is the cofactor of prolyl- and lysylhydroxylases, which are involved in the collagen biosynthesis in the osseous tissue (28). The lack of iron can cause osteoporosis, In the present study we pointed out that iron levels were significantly related to bone type. Ac- 
Maksym Pogorielov, Evgenii Gusak, Sergii Danilchenko et al.

cordingly, in the lumbar vertebra the Fe concentration was nearly two times higher than in tibia and femur. This indicates that there is better blood supply in sponge bones and also a higher metabolism level.

$\mathrm{Cd}$ is involved in the ossification process. When its level is high, it results in osteoporosis and osteomalacia (29). Due to increased calcium excretion by urine, there is a decreased calcium absorption by the intestinal tract. Cd ions can be absorbed by hydroxylapatite crystals and input on the crystalline grid and thus make the derived substance slightly soluble (30). A negative effect of $\mathrm{Cd}$ on osseous tissue mineralization process was observed and it increased due to its synergetic interaction with iron ions, since iron citrate inhibits biological calcification. The osseous tissue contained trace amounts of cadmium in the femur and tibia in concentrations of $0.025 \pm 0.001 \mu \mathrm{g} / \mathrm{g}$ and $0.025 \pm 0.002 \mu \mathrm{g} / \mathrm{g}$, respectively. Cd absence in lumbar vertebrae results in decreased mineralization and bone strength of this type of bones. $\mathrm{Pb}$ and $\mathrm{Ni}$, which are toxic elements, were mainly found in the tubular bones, which have less remodeling intensity.

Analyzing the elementary composition of different bone types we have figured out some diversity in microelement concentrations. The lumbar ver- tebrae revealed higher concentrations of certain elements, but at the same time the femur and tibia had nearly the same element contents. These results indicate that the lumbar vertebrae have better blood supply than the femur and tibia bone. Besides, femur and tibia contain $\mathrm{Cd}$ and this explains their absorption ability.

The total result of bioelement quantity content shows that the bones have the highest concentration of $\mathrm{Zn}$ and $\mathrm{Mg}$. Beside their biochemical role they have a mechanical function as well and the osseous tissue works as a storage place for these elements. Consequently, bones contain the smallest amounts of $\mathrm{Pb}$ and $\mathrm{Cd}$ which can be explained by their biochemical function only in small concentrations.

It is highly important to identify the interactions between these elements.

The study of biochemical microelement interaction, when the osseous tissue is taken as an example, is really significant since these microelements are parts of enzyme systems. The derived correlation coefficients were negative as well as positive with different interaction measures (figure 1). A negative correlation coefficient, which has the highest reliability rank, was found between Fe and $\mathrm{Zn}$. This antagonis-

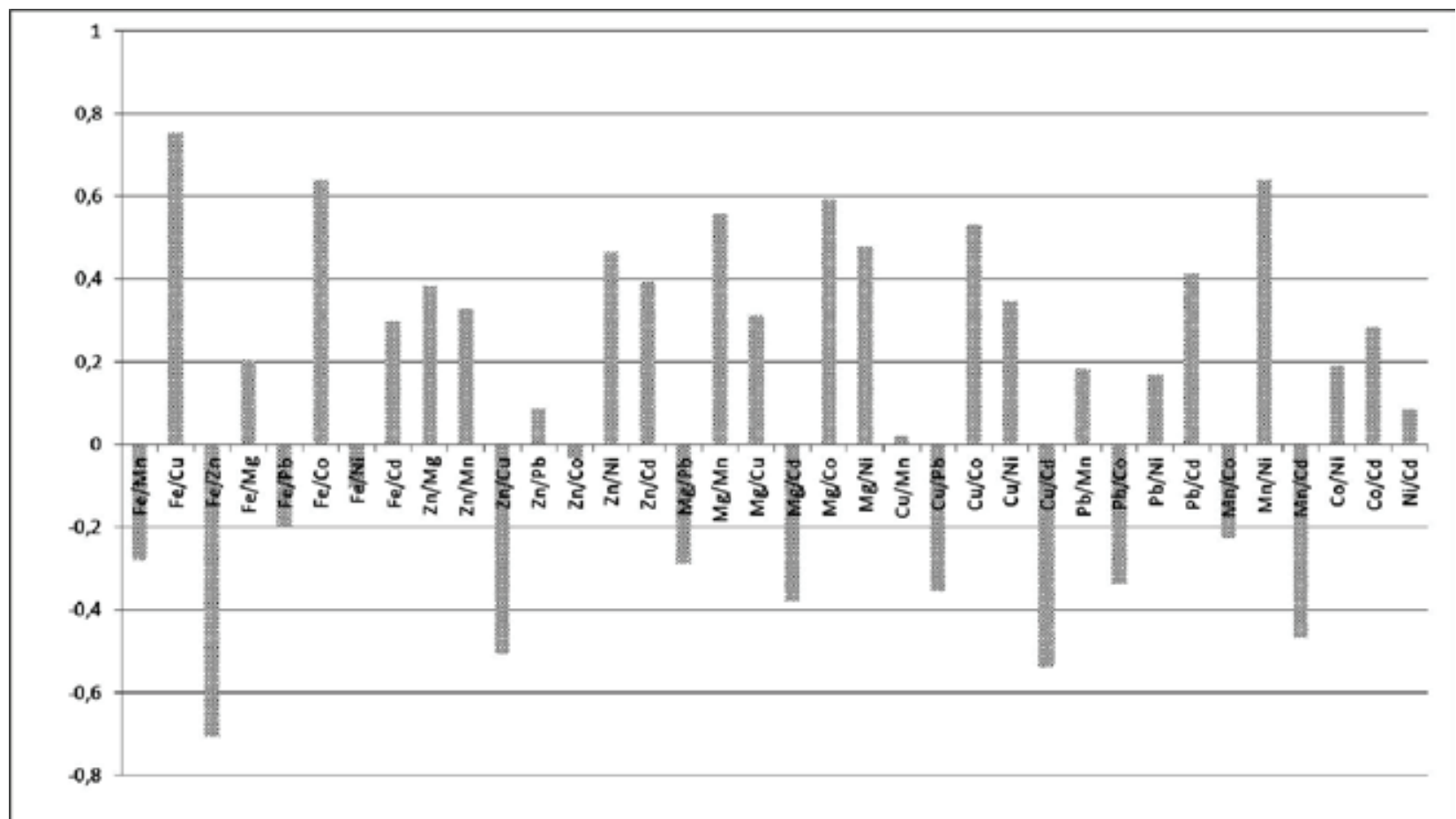

Fig. 1. The interaction correlation coefficients of osseous tissue trace elements 
tic interaction can be clarified by the inhibitory effect of zinc on iron-containing cytochrome oxidase and catalase. Positive element interaction with high reliability rank was observed between $\mathrm{Fe}$ and $\mathrm{Cu}, \mathrm{Fe}$ and $\mathrm{Co}, \mathrm{Mn}$ and Ni. By means of coefficients of multiple correlation it was evaluated that $\mathrm{Fe}, \mathrm{Cu}, \mathrm{Zn}$ and $\mathrm{Mn}$ were most active in correlation with other elements.

\section{CONCLUSIONS}

The elemental analysis of different bone types shows diversities between tubular and irregular bones microelement composition. The lumbar vertebrae contain a great amount of essential elements, which is related to their remodeling activity and availability of enzymes. Mostly the long bones store toxic elements, such as $\mathrm{Ni}$ and $\mathrm{Pb}$.

This indicates a lower speed of the remodeling speed process of compact substance. Thus, elementary bone compounds directly depend on osseous tissue structure.

Correlation analysis of data showed that osseous tissue had weak positive microelement correlation interactions, while negative interactions were partly identified. The low correlation coefficient values are justified by the fact that normal osseous tissue is a sufficiently stable system. That's why these values can be used as standard measurements for further microelement interaction researches of various osseous tissue pathologies.

\section{REFERENCES}

1. Sonne C., Riget F.F., Beck Jensen J.E. et all. Does the nutrition profile of vitamins, fatty acids and microelements counteract the negative impact from organohalogen pollutants on bone mineral density in Greenland sledge dogs (Canis familiaris)? Environ Int, 2008;34(6):811-820.

2. Jill W.-S., Elena A., Robert A. L. et all. Mitral Valve Endothelial Cells With Osteogenic Differentiation Potential. Arterioscler Thromb Vasc Biol, 2011;31:598-607.

3. Clive N. Trueman and Noreen Tuross Trace Elements in Recent and Fossil Bone Apatite. Reviews in Mineralogy and Geochemistry, 2002;48:489-521.

4. Om A.S., Shim J.Y. Effect of daidzein, a soy isoflavone, on bone metabolism in Cd-treated ovariectomized rats. Acta Biochim Pol, 2007; 54(3):641-646.
5. Molina W., Pino S., Sosa G., Hernandez L. Distribution of mucopolysaccharides and glycoproteins in the articular discs of temporomandibular joints in human fetuses. J Orofac Pain, 2005; 19(4):325-330.

6. Ristori G., Brescianini S., Pino A.et all. Serum elements and oxidative status in clinically isolated syndromes: Imbalance and predictivity. Neurology, 2011;76: 549-555.

7. Windisch $W$ Interaction of chemical species with biological regulation of the metabolism of essential trace elements. Anal Bioanal Chem, 2002;372(3):421-425.

8. Christine L. E., Sujuan G., Yiming L. et all. Trace Element Levels in Drinking Water and Cognitive Function among Elderly Chinese. Am. J. Epidemiol., 2000;151:913-920.

9. Kotyzova D, Cerna P, Leseticky L, Eybl V Trace elements status in selenium-deficient rats--interaction with cadmium. - Biol Trace Elem Res, 2010, No 136(3), 287-293.

10. Zhong L. Y., Zheming N. General Computer Program (AAS-TOOLS) for Theoretical Studies in Electrotermal Atomic Absorption Spectrometry. J. Analit. Atom. Spectrometry, 1994; 9:669-673.

11. Sunderman F.W., Marzouk A., Crisostomo M.C. Electrothermal atomic absorption spectrophotometry of nickel in tissue homogenates. Annals of Clinical and Laboratory Science, 2001;15(4):299-307.

12. Butala S.J., Scanlan L.P., Chaudhuri S.N. Atomic absorption spectrophotometry methodology for the quantitative analysis of mercury in fish and hair. J Food Prot, 2006;69(11):2720-2728.

13. Zareba S., Szarwilo K., Pomykalski A. Determination of $\mathrm{Fe}$ (II) and Zn (II) by spectrophotometry, atomic absorption spectrophotometry and ions chromatography methods in Vitrum. Farmacology, 2005;60(5):459-464.

14. Scancar J, Milacic R, Benedik M, Bukovec P Determination of trace elements and calcium in bone of the human iliac crest by atomic absorption spectrometry. Clin Chim Acta, 2000;293(1-2):187-197.

15. Zaksas NP, Sultangazieva TT, and Gerasimov VA Determination of trace elements in bone by two-jet plasma atomic emission spectrometry. Anal Bioanal Chem, 2008;391(2):687-693.

16. Heugten E., Spears J. W., Kegley E. B. et all. Effects of organic forms of zinc on growth performance, 
Maksym Pogorielov, Evgenii Gusak, Sergii Danilchenko et al.

tissue zinc distribution, and immune response of weanling pigs. J Anim Sci, 2003;81:2063-2071.

17. Maurizio Z., Shmuel Y., Lisa P. et all. A prospective evaluation of the biochemical, metabolic, hormonal and structural bone changes associated with bortezomib response in multiple myeloma patients. Haematologica, 2011;96:333-336.

18. Taisun H. H., Elizabeth Barrett-Connor, David B. $\mathrm{M}$. Zinc intakes and plasma concentrations in men with osteoporosis: the Rancho Bernardo Study. Am J Clin Nutr, 2011;80:715-721.

19. Nishimuta M Mini-review. The concept of intracellular, extracellula- and bone-minerals. - BioFactors, 2000;12:35-38.

20. Kodama N, Nishimuta M, Suzuki K Negative balance of calcium and magnesium under relatively low sodium intake in human. J Nutr Sci Vitaminol, 2003;49:201-209.

21. Qi Dai, Martha J Shrubsole, Reid M Ness The relation of magnesium and calcium intakes and a genetic polymorphism in the magnesium transporter to colorectal neoplasia risk. Am J Clin Nutr, 2007;86:743-751.

22. Disilvestro, R. A., Marten J. T. Effects of inflammation and copper intake on rat liver and erythrocyte $\mathrm{Cu}-\mathrm{Zn}$ superoxide dismutase activity levels. J. Nutr, 1990;120:1223-1227.

23. Engle, T. E., Spears J. W. Effects of dietary copper concentration and source on performance and copper status of growing and finishing steers. - J. Anim. Sci., 2000, No 78, 2446-2451.
24. Keen C.L, La-nnerdal B., Hurley, L. Manganese. In: Biochemistry of the Essential Ultratrace Elements. Frieden, E., ed., Plenum, New York, 1984:89-132.

25. Thomas IT, Evans EJ. The effect of cobalt-chromium-molybdenum powder on collagen formation by fibroblasts in vitro. Biomaterials, 1986;7:301-304.

26. Haynes DR, Rogers SD, Hay S. The differences in toxicity and release of bone-resorbing mediators induced by titanium and cobalt-chromium-alloy wear particles. - J Bone Joint Surg (Am), 1993;75-A:825-834.

27. Roy CN, Enns CA. Iron homeostasis: new tales from the crypt. - Blood, 2000;96:4020-4027.

28. Ardehali R, Shi L, Janatova J, Mohammad SF, Burns GL. The effect of apo-transferrin on bacterial adhesion to biomaterials. Artif Organs, 2002;26:512-520.

29. De La Fuente H. D., Portales-Perez D., Baranda L. Effect of arsenic, cadmium and lead on the induction of apoptosis of normal human mononuclear cells. Clin. Exp. Immunol, 2002;129:69-77.

30. Blakley B. R. The effect of cadmium chloride on the immune response in mice. Can. J. Comp. Med, 1985;49:104-108. 